\title{
Social Inequality and the University
}

\author{
Werner Georg \\ University of Konstanz. Germany \\ Werner.Georg@uni-konstanz.de
}

\begin{abstract}
Since Pierre Bourdieu's early work on «Reproduction», social inequality in the educational system and especially at university level was in the focus of sociological interest. On the background of Bourdieu's capital theory this contribution poses the question of how students from different social strata accumulate economic, social and cultural capital at the university. On the basis of a student survey conducted at the regions of Baden-Württemberg, Rhone-Alps and Catalunia, a comparison is made by means of a correspondence analysis. As a result it can be shown Baden-Württenberg displays the strongest social inequalities at university level, followed by Rhone-Alps and Catalonia. While Baden-Württemberg and Rhone-Alps show the same pattern of social inequlity (a dominance of economic disparities), the connection between social strata and university system seems to be quite different in Catalonia.
\end{abstract}

Key words: Bourdieu, reproduction theory, social inequality, university, student survey, comparison of european regions.

\section{Resum. Desigualtats socials i universitat}

Des del primerenc treball de Pierre Bourdieu a «Reproduction», la desigualtat social al sistema educatiu i especialment a nivell universitari ha estat un focus d'interès sociològic. A la base de la principal teoria de Bourdieu, s'hi planteja la qüestió de com estudiants de diferents estrats socials acumulen capital econòmic, social i cultural a la universitat. Basantse en una enquesta a estudiants, duta a terme a les regions de Baden-Württemberg, RhoneAlps i Catalunya, es duu a terme una comparació mitjançant una anàlisi de correspondències. Com a resultat, es mostra com Baden-Württenberg presenta les desigualtats socials més importants a nivell universitari, seguit per Rhone-Alps i Catalunya. Mentre que BadenWürttemberg i Rhone-Alps presenten el mateix patró de desigualtat social (una preponderància de les desigualtats econòmiques), la connexió entre classes socials i sistema universitari sembla que és força diferent a Catalunya.

Paraules clau: Bourdieu, teoria de la reproducció, desigualtat social, universitat, enquesta a estudiants, comparació entre regions europees.

\section{Summary}

1. Theoretical background

2. Measures and Data

3. Analysis
4. Discussion

References 


\section{Theoretical background}

Already in his work on social «Reproduction» (Bourdieu and Passeron, 1971), the French sociologist Pierre Bourdieu described the university as a field defined by a social game. The name of this game is «equality", i. e. both professors and students feign a situation where all participants are equal in terms of the social status of their origins. Bourdieu (1986) distinguishes three kinds of capital: economic capital, cultural capital and social capital. He uses the metaphor "capital» instead of «resources» in order to avoid having to split the social world into a strategically oriented economical sphere and an «innocent» cultural sphere engaged in «l'art pour l'art». The capital theory assumes that cultural capital is a means for the transmission of social status and can be converted into economic and social capital, or in more general terms, that all kinds of capital can be converted into each other.

Cultural capital is differentiated in three sub-types: incorporated cultural capital, institutionalised cultural capital and objective cultural capital. It takes a long time for incorporated cultural capital to accumulate and this process takes place in the family of origin during early childhood. According to this theory elements of the life-world like antique furniture, original pieces of artwork, classical music, a private library, a photo-wallpaper that displays a sunrise on the seaside, popular music and yellow press literature determine the primary perception and the development of evaluative and cognitive schemes of the child. Institutionalised cultural capital is a result of educational achievements in educational institutions that have the power to definite what is «important» and «unimportant» knowledge. It is transmitted in a rational, controlled and defined way, as outlined in the curricula of the educational institutions. Finally, the objective cultural capital refers to artefacts in the cultural field, such as books, pieces of artwork or the possession of special music instruments etc.

How can social inequality in the educational system be explained by the concept of cultural capital? At the begin of their educational careers, pupils start with different amounts of incorporated cultural capital and possess a certain habitus consistent with this capital. However, the educational system operates with the assumption of equality in the starting conditions and treats students with different amounts of cultural capital as if they were equal in this respect. Although cultural capital is socially constructed in special spheres of the social structure, it is treated by the school and university as a "natural» ability of the students. Such a mystification means that classes with a high amount of cultural capital are able to transmit their status in a legitimised way. Educational success signifies in this kind of reasoning that the habitus of the family of origin corresponds with the one, that is useful at the university for the development of adequate learning behaviour and self efficacy convictions.

Generally speaking, in the lower classes there is a mismatch between the habitus of origin and the academic habitus necessary in order to use the university as a field for the accumulation of resources useful in one's future pro- 
fessional career. Students from lower social strata have less of these three resources at their disposal when they enter a university and are less able to accumulate them during their academic careers.

One way to unmask the «equality game» described above might be to observe the behavior of students from different social origins in fields connected to the accumulation of economic, cultural and social capital during their study. The general question behind this procedure is not how students learn the specialized knowledge of their subjects, but how they act in order to accumulate what one would call nowadays «soft-skills» and extra-curricular abilities that will enable them during their professional careers to acquire competitive advantage compared to their colleagues from the lower classes.

I invite you in this paperast a look behind the rules of the «equality game», to investigate whether Bourdieu's assumptions from the late 60 s are still valid and, if you want, to draw some practical conclusions from the following findings for the current university policies.

\section{Measures and Data}

As the design of the international comparative study has already been worked out, I will limit this chapter to a description of the measures used for the analysis. In order to operationalize social inequality as a composed measure including occupational status and educational attainment, the problem arose that not all combinations of both variables occur with a statistically adequate frequency. As a result, the classification had to be developed on the basis of empirical distributions. The following groups were computed:

- Lower class with low educational level: unskilled workers and employees with a primary education.

- Lower class with higher educational level: unskilled workers and employees with more than a primary school education.

- Middle class with low educational level: skilled workers, employees and civil servants with a primary school or middle school educational level.

- Middle class with high educational level: skilled workers, employees or civil servants above this level.

- Upper class with low educational level: executives in the private or public sector and professionals with an education below the university level.

- Upper class with high educational level: professional groups with a university degree.

For a performance analysis based on the accumulation of economic, cultural and social capital, 36 variables with the following assignments were selected:

Economic Capital:

- Being completely financed by parents.

- Reception of public subsidies by parents.

- Gainful employment during school term. 
- Gainful employment during semester breaks.

- Gainful employment necessary to finance university education.

- Stress with regard to present financial situation.

- Stress with regard to future financial situation.

Cultural Capital:

- Security to begin university studies.

- Good information status on conditions of study.

- Good information status on studying abroad.

- Attending lectures in other subjects.

- Attending courses in foreign languages.

- Attending courses in soft skills.

- Attending courses on computers and software.

- Intention to attend lectures in other subjects in the future.

- Intention to attend public lectures in the future.

- Intention to attend courses on soft skills in the future.

- Intention to attend computer courses in the future.

- Job as a student assistant.

- Already having studied abroad.

- Having a job in a research project.

- Intention to study abroad.

- Intention to take a language course abroad.

- Intention to write a doctoral thesis.

- Difficulties due to demands for achievement.

- Interest in politics and public life.

- Interest in the fine arts and culture.

- Interest in science and research.

Social Capital:

- Frequent contacts with teaching staff.

- Satisfactory contacts with other students.

- Satisfactory contacts with teaching personnel.

- Difficulties in contacts with teaching personnel.

- Stress caused by the anonymity of the university.

It has to be mentioned that these assignments are poor measures in some aspects. Firstly, students in different semesters were surveyed, and in order to correct for this fact, both the attendance of different courses and the intention to attend them in the future had to be considered. Secondly, one might argue that the accumulation of economic capital during the course of study (gainful employment) is not primarily a result of a certain habitus in itself, but rather a reaction to material shortcomings resulting from one's position in the hierarchy of social status. However, the alternative to this procedure would be, to play the «equality-game» mentioned above and simulate a situation where all students are equal in a material sense. 


\section{Analysis}

To begin with a first overview of the situation in the three regions, it is interesting to evaluate the rate of academic self-recruitment at universities. Table 1 contains the corresponding information.

Apparently the social closure of the university system is strongest in BadenWürtemberg and weakest in Catalonia, with Rhone-Alps in the middle position. A more differentiated picture can be drawn if one considers the parents' highest occupational level (table 2).

The results in table 1 are underscored by the findings in table 2: the probability that the child of a skilled worker will attend a university are, in Rhone Alps three times and in Catalonia nearly 6 times higher than in BadenWürttemberg. The opposite structure can be shown for executives and professionals: while $60 \%$ of their children attend a university in BadenWürttemberg, only 45\% do so in Rhone-Alps and 25\% in Catalonia.

In his statistical analysis in «Reproduction», Bourdieu shows that there is a hierarchy of subjects depending on social origins. At the top are the traditional faculties of Medicine and Law, while the humanities, social and educational sciences rank at the bottom. In this connection the question can arise of whether this hierarchy still exists in the three regions that were surveyed. Table 3 displays the distribution of students whose parents studied at universities for seven classes of subjects.

These results underscore Bourdieu's findings from the 60s, insofar as Medicine and Law have the highest proportion of students with universityeducated parents in all three regions, and in all the humanities and social sciences show the lowest proportion in this respect. However, this connection is far from being deterministic, and as a surprising result we notice the high pro-

Table 1. Academic Self-Recruitment in Baden-Württemberg, Rhone-Alps and Catalonia.

\begin{tabular}{ll}
\hline Baden-Württemberg & $58.8 \%$ \\
Rhone-Alps & $45.7 \%$ \\
Catalonia & $31.3 \%$ \\
\hline
\end{tabular}

Table 2. Representation of children from families in different professional groups in universities in Baden-Württemberg, Rhone-Alps and Catalonia (percentages).

\begin{tabular}{lcccc}
\hline & $\begin{array}{c}\text { Unskilled workers } \\
\text { and employees }\end{array}$ & $\begin{array}{c}\text { Skilled workers } \\
\text { and employees }\end{array}$ & $\begin{array}{c}\text { Qualified workers } \\
\text { and employees }\end{array}$ & $\begin{array}{c}\text { Executives and } \\
\text { professionals }\end{array}$ \\
\hline Baden- Württemberg & 2.1 & 8.1 & 30.0 & 60.1 \\
Rhone-Alps & 6.0 & 25.1 & 24.3 & 44.7 \\
Catalonia & 5.6 & 45.0 & 24.8 & 24.7 \\
\hline
\end{tabular}


Table 3. Distribution of students from an academic background in seven subjects in Baden-Württemberg, Rhone-Alps and Catalonia.

\begin{tabular}{lccc}
\hline & Baden-Württemberg & Rhone-Alps & Catalonia \\
\hline Humanities & 50.3 & 41.8 & 29.9 \\
Social Sciences, Psychology, Pedagogy & 55.1 & 35.0 & 24.9 \\
Law & 66.0 & 54.1 & 37.6 \\
Economics & 63.6 & 46.9 & 29.8 \\
Medicine & 73.4 & 68.3 & 43.7 \\
Natural Sciences & 53.1 & 45.7 & 29.8 \\
Engineering & 61.2 & 47.6 & 34.4 \\
\hline Average & 58.8 & 45.7 & 31.3 \\
\hline
\end{tabular}

portion of students with university-educated parents in engineering, which in earlier studies were the subjects chosen by students from the lower classes interested in upward mobility. One reason for this result in Baden-Württemberg could be that the sample contains a technical university (Karlsruhe), and the path for academic upgraders in the first generation normally leads to universities for applied sciences (Fachhochschulen) rather than to technical universities, which rank higher in prestige, academic demands and study duration.

After having examined the basic conditions of social inequality at universities, the focal question of this paper has to be surveyed, namely how students from different social backgrounds behave in regard to the accumulation of economic, cultural and social capital. Normally one would have to interpret the cross-tabulation of the 36 variables described above with the six groups which were composed according to occupational status and educational achievement. This procedure would be quite lengthy and time consuming. However, there is a statistical method called "correspondence analysis» that allows us to project the principal structure of the data onto a two-dimensional space (Benzécri, 1979; Greenacre, 1984; Hirschfeld, 1935). I will not enter into the statistical basis of this procedure, but it has to be explained that the columns (i. e. our six groups composed in terms of occupational status and educational attainment) and the rows (i. e. the variables which operationalize the accumulation of capital) are projected separately onto a two-dimensional space, and their neighborhood in this space can be interpreted accordingly. This means, for example, that if interest in the fine arts is positioned near the upper class with university degrees, both features have commonalities in the data structure.

\subsection{Correspondence Analysis for Baden-Württemberg}

The two-dimensional solution displays one dominant first axis that explains $68.2 \%$ of the variation in the data and a second, subdominant one that con- 


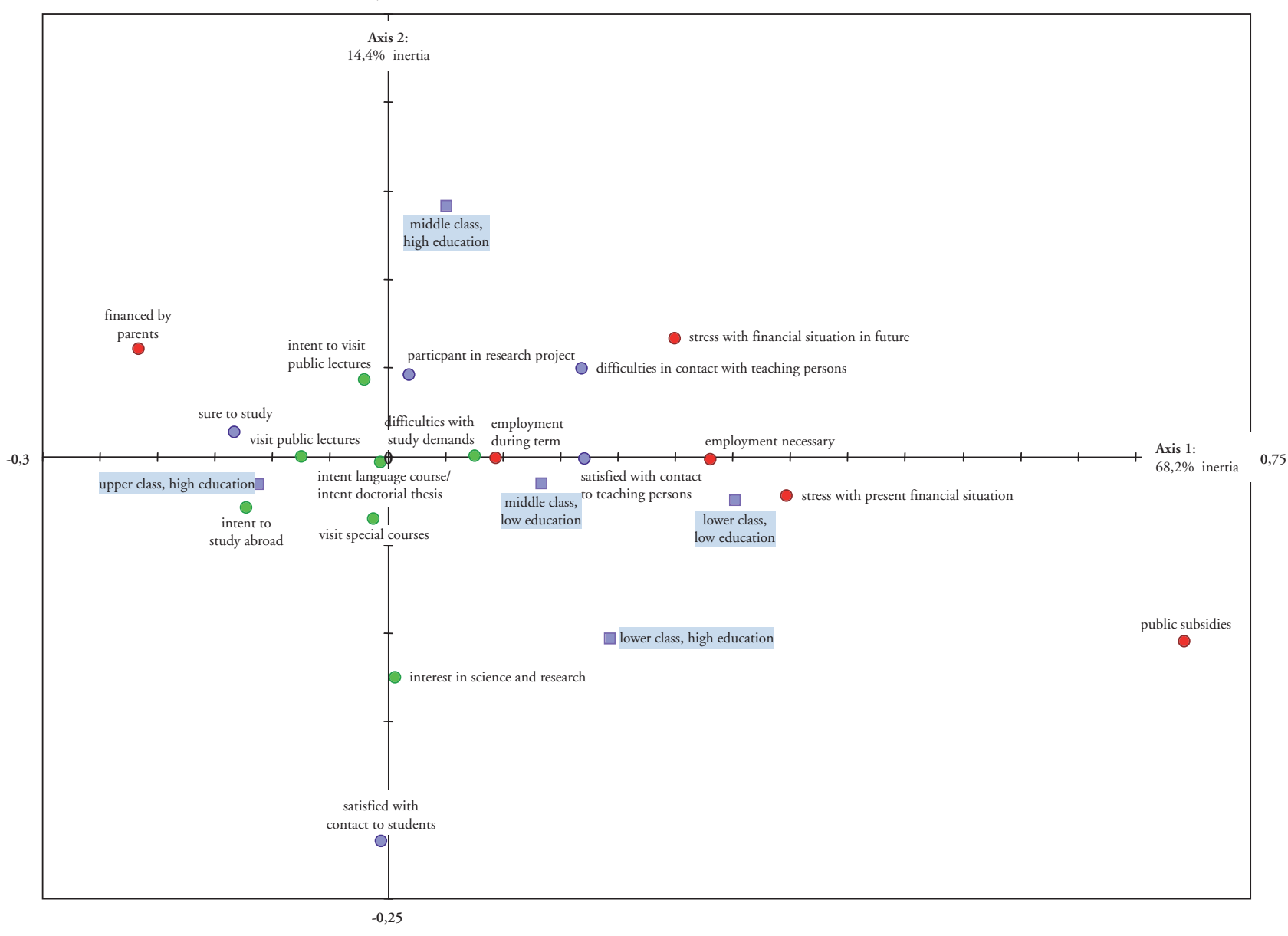

Figure 1. Correspondence Analysis Baden-Württemberg. 
tributes $14.4 \%$. For this reason it seems legitimate to limit the interpretation to the first axis, which represents two-thirds of our variation. If we examine the first axis, it is obvious that it is ordered from the right to the left in terms of increasing social status. On the right extreme we have the lower class with low educational level, and on the left end the upper class with high educational level. According to our behavioral attributes, the right extreme is defined by the reception of public subsidies and the left one by being financed completely by parents. Generally speaking, the three lowest status groups on the right part of the axis are connected with different kinds of worries and problems: stress about the financial situation in the present and the future, having to work during the school term, difficulties in contacts with teaching personnel and with the demands of university study are typical for the situation of these groups. On the other hand, the left part of the axis is defined by the upper class with high educational level. This status group, which often is completely financed by its parents, is sure of being able to begin studying, has the intention to study abroad, to attend language courses and to write a doctoral thesis. These privileged situations are completed by the frequent attendance of public lectures and courses that teach soft skills.

The logic of the interpretation of correspondence analysis is that attributes at the extremes of the axis contribute most to the solution and are the most important for their semantic definition. In accordance with this rule, it is apparent that differences in economic capital (being financed completely by parents or receiving public subsidies, having to work during the school term and experiencing stress regarding one's financial situation) are the most important and that distinctive patterns related to cultural or social resources, such as difficulties with demands and the attendance of public lectures, rank lower in their contributions.

\subsection{Correspondence Analysis for Rhone-Alps}

The solution for Rhone-Alps displays a very similar structure compared to Baden-Württemberg. The first axis explains $78 \%$ of the variation, while the second one makes only a contribution of $8.9 \%$ in this regard. As in BadenWürttemberg, the status groups have a consistent order, from the lower class with low educational level on the right part of the axis to the upper class with high educational level on the left. Generally speaking, an opposition between the three lowest and two highest status groups is constructed by the first axis. The corresponding attributes on the level of study behavior, as in BadenWürttemberg, show the contrast of receiving public subsidies and being financed by parents. The university study of the three lowest groups is characterized by stress due to the financial situation in the present and the future, a need for gainful employment during the school term and semester break and difficulties in contacts with teaching personnel and the demands of the subject. Typical for the upper class with high and low educational level is, in contrast, a job as a student assistant, an intention to study abroad and the attendance of courses 


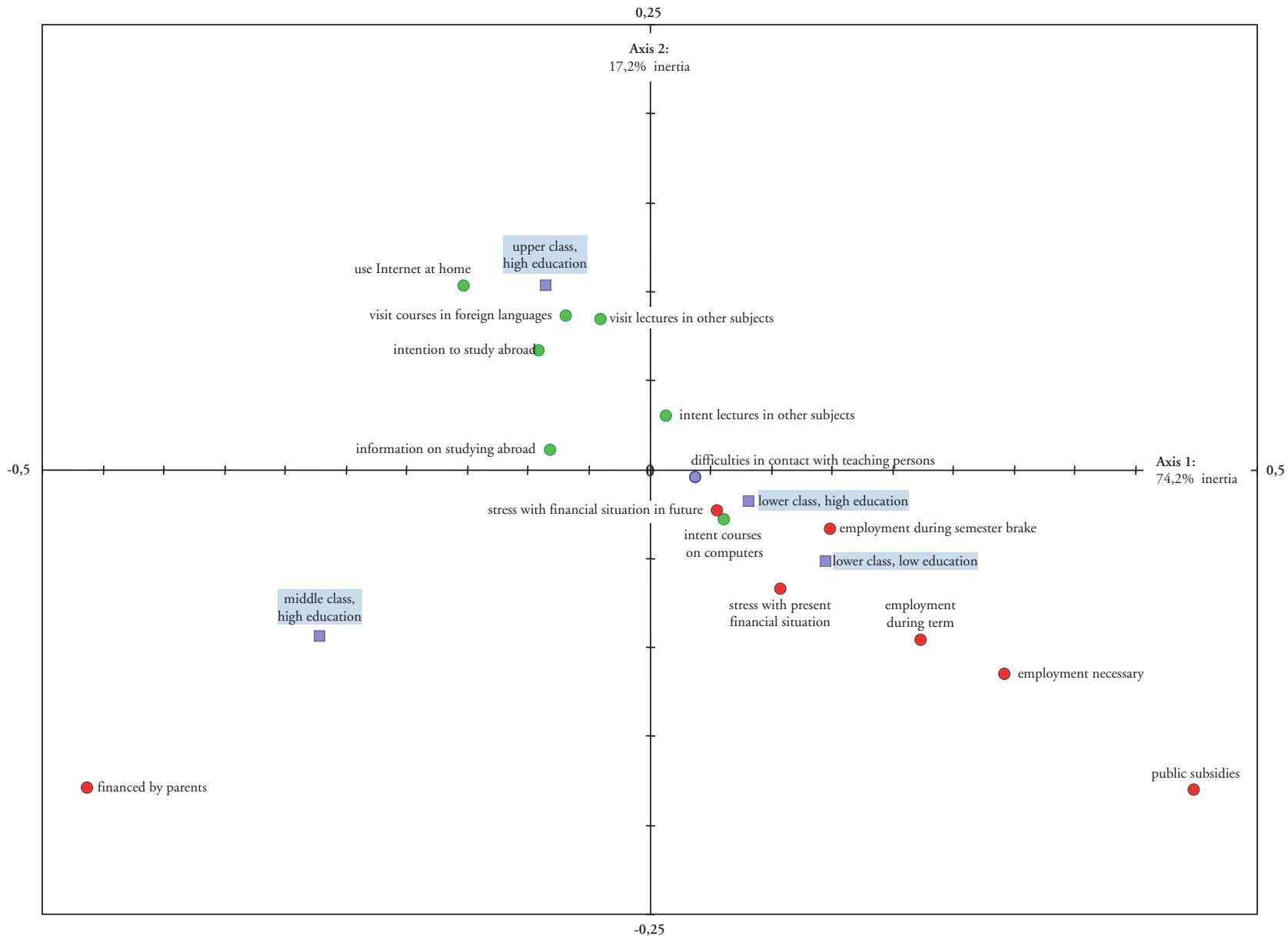

Figure 2. Correspondence Analysis Rhône-Alps. 
in a foreign language, soft skills, in other subjects or of public lectures. This groups also displays a higher proportion of students who have already studied abroad and are sure of being able to begin their university studies. Additionally, they have a general interest in the fine arts and culture. To sum up, Rhone-Alps shares a lot of commonalities with Baden-Württemberg, based on the order of the status groups and the overriding importance of economic resources for university study. However, it seems that the cultural features of the upper class are a bit more distinctive than in our German region.

\subsection{Correspondence Analysis for Catalonia}

In Catalonia we have a somewhat different structure than in Rhone-Alps and Baden-Württemberg. Firstly, the most important status differences are between the two groups of the lower class and the highly-educated persons from the middle and upper classes. It seems that a high educational level is more important for the differentiation of university study in Catalonia than high occupational status. Once again, the dominant opposition of the first axis is constructed by receiving public subsidies or being financed by parents. Besides the typical situation of the two lowest status groups that was already described for the other regions (financial problems, gainful employment, difficulties with teaching staff), we notice the intention to attend computer courses and lectures in other subjects in the future. The middle and upper classes with high educational levels show less distinctive patterns than in Baden-Württemberg and Rhone-Alps: they attend courses in foreign languages and other subjects, frequently use the Internet at home and intend to study abroad.

\section{Discussion}

A first approach to the effects of social inequality in the three regions shows the same pattern according to different measures such as educational attainment or occupational status: most selective for person from a low educational or professional status is the university system of Baden-Württemberg, a middle position is occupied by Rhone-Alps, and the most equalitarian situation is found in Catalonia. From the data at hand it cannot be determined what causal processes lead to this differentiation: the general closure of the social structure, the particularities of the educational system or the development of the labor market. However, what we can survey with our data are the effects of different social backgrounds on the course of the study depending on economic, cultural and social resources. To begin with the commonalities in all three regions: most distinctive was disposal over (or lack of) economic resources, with the consequence of having to work during the school term or semester break. Connected with this effect was stress due to the economic situation in the present and the future. From other analyses we know that a gainful employment of eight hours or more per week has severe consequences for the performance and the duration of university study. From this result it can be 


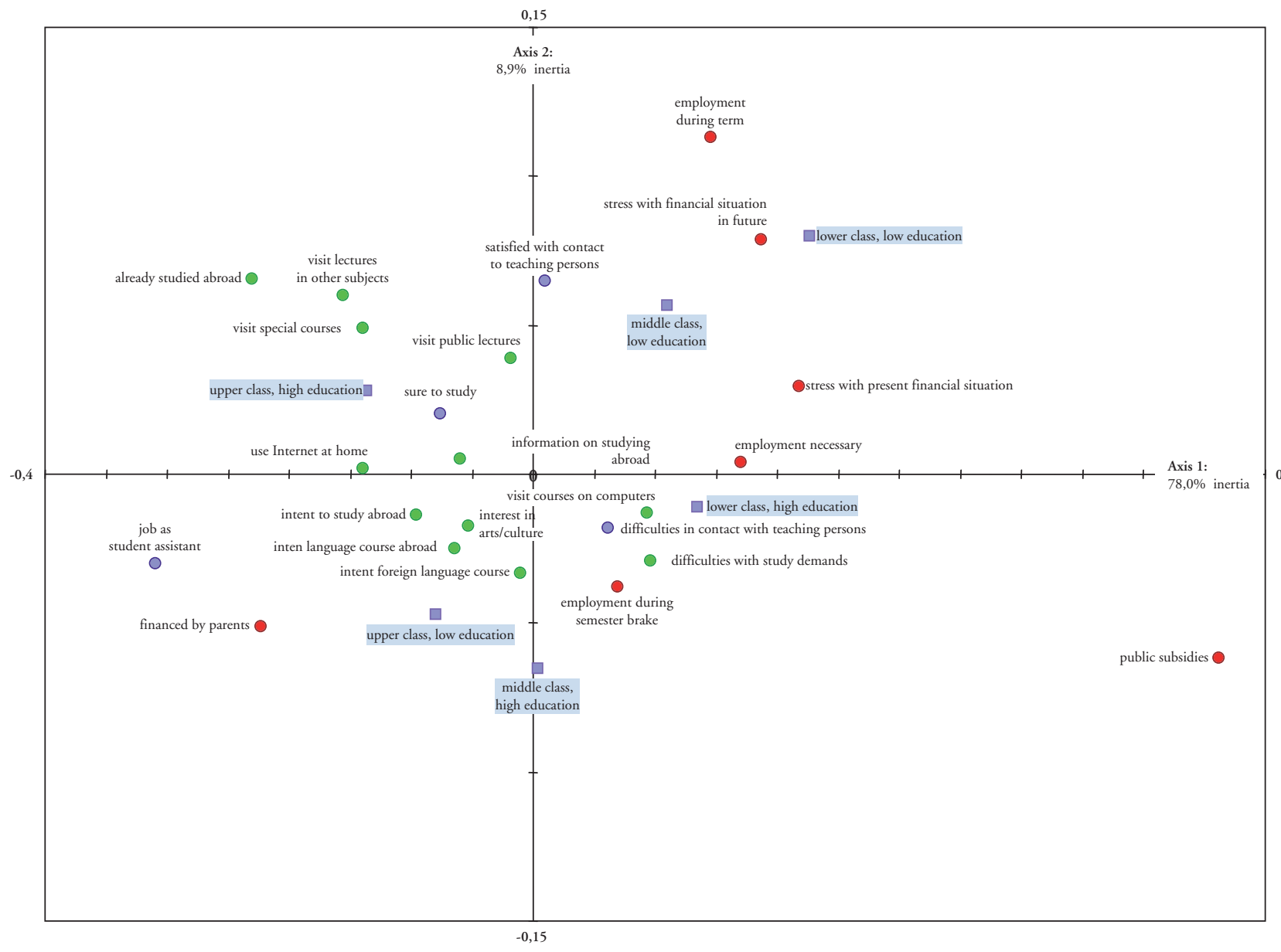

Figure 3. Correspondence Analysis Catalonia. 
deduced that access to public subsidies in all three regions, but above all in Baden-Württemberg, is insufficient and has negative consequences for the course of study of students from the lower class. In order to correct for this disadvantage, the system of public subsidies should be expanded, and the amounts made available should be increased.

A second common finding was, that students from a lower-class background have difficulties in relating to the teaching staff. Whether these difficulties arise because of a lack of self-confidence or due to specific conditions in the interactions between teaching staff and students from the lower class cannot be decided here. However, it is obvious that there is a need for better consultation with the teaching personnel, and this should be incorporated into the institutional frameworks of the departments.

\section{References}

BENZECRI, J.P. et collaborateurs (1973). L'Analyse des Donées. L'Analyse de Correspondence. Paris.

BourdiEu, P. (1986). Die feinen Unterschiede. Zur Kritik der gesellschaftlichen Urteilskraft. Frankfurt am Main.

Bourdieu, P.; PAsSeron, J.C. (1971). Die Illusion der Chancengleichheit. Stuttgart. GreENACRE, M. (1984). Theory and Application of Correspondence Analysis. London. HirsCHFELD, H.O. (1935). «A Connection between Correlation and Contingency», Proceedings of the Cambridge Philosophical Society, 31, 520-524. 